\title{
Isolation, Detection and Genomic Differentiation of Vibrio cholerae and Vibrio parahaemolyticus in Bachok, Kelantan
}

\author{
Vimala B. ${ }^{1,2}$, Thong Kwai Lin ${ }^{1,2} *$ and Chong V. C. ${ }^{1}$ \\ ${ }^{1}$ Institute of Biological Sciences, Faculty of Science \& ${ }^{2}$ BioMedical Science and Molecular Typing Laboratory, \\ Institute of Postgraduate Studies, University of Malaya, 50603 Kuala Lumpur, Malaysia. \\ * thongk1@um.edu.my (corresponding author) \\ Received on $24^{\text {th }}$ April 2009, accepted in revised form $22^{\text {nd }}$ September 2009.
}

\begin{abstract}
The objective of this study was to determine the genetic diversity and virulence factors of Vibrio cholerae and $V$. parahaemolyticus from selected aquatic environments in Bachok, Kelantan, Malaysia. Out of 50 water samples, 33 were confirmed with the presence of presumptive $V$. cholerae and $V$. parahaemolyticus based on biochemical tests. Primers targeting toxR gene specific for $V$. cholerae (800bp) and $V$. parahaemolyticus (368bp), $t d h(251 \mathrm{bp})$ and $t r h(250 \mathrm{bp})$ virulence genes were used in the PCR. Results of PCR showed that only 25 isolates of $V$. parahaemolyticus and 3 of $V$. cholerae had the toxR gene. None of the $V$. parahaemolyticus isolates had the trh and $t d h$ genes. Repetitive extragenic palindromic PCR (REP-PCR) was used to determine the relatedness of these strains at the genomic level. Cluster analysis for REP-PCR showed 2 major clusters A-B, with several isolates from different locations grouped together indicating the geographical relatedness due to interconnected waterways. REPPCR showed that the species of Vibrios are genetically diverse.
\end{abstract}

ABSTRAK Objektif kajian ini adalah untuk menentukan diversiti gen and faktor-faktor virulen Vibrio cholerae dan Vibrio parahaemolyticus yang diperolehi di sekitar perairan Bachok, Kelantan. Sejumlah 33 daripada 50 sampel air yang diuji melalui kaedah biokimia didapati positif untuk $V$. cholerae dan $V$. parahaemolyticus. Bagi amplifikasi PCR, primer toxR yang spesifik kepada $V$. cholerae (800bp) dan $V$. parahaemolyticus (368bp) serta primer-primer untuk mengesan gen-gen virulen seperti $t d h(251 \mathrm{bp})$ and trh $(250 \mathrm{bp})$ juga digunakan. Hasil PCR menunjukkan hanya 25 strain $V$. parahaemolyticus dan 3 strain $V$. cholerae mempunyai gen toxR. Tiada gen virulen dikesan pada mana-mana strain $V$. parahaemolyticus. REP-PCR diaplikasi untuk menentukan hubungan antara strain-strain yang telah diasingkan dalam kajian ini. Analisis dendrogram bagi REP-PCR menunjukkan 2 kumpulan utama, A-B. Strain-strain yang berasal dari lokasi yang berbeza dikumpulkan bersama. Ini mungkin disebabkan oleh faktor geografi di mana sistem perairan yang berkaitan. Keputusan REP-PCR menunjukkan variasi genetik yang nyata di dalam spesies Vibrio.

(Keywords: Vibrios, toxR, tdh, trh, REP-PCR)

\section{INTRODUCTION}

Vibrio spp. are natural inhabitants of freshwater, estuarine and seawater environments. Therefore, the aquatic environment acts as a reservoir and source of their transmission [1]. In this study, we have focused on $V$. cholerae and $V$. parahaemolyticus since these two Vibrio spp. are potential, emerging water-borne pathogens responsible for negative impact to humans, marine animals and aquaculture [2, 3]. Few studies conducted in Malaysia, however, have indicated the prevalence of $V$. parahaemolyticus and $V$. cholerae in foods, environment and clinical samples $[4,5,6,7]$.

Vibrio cholerae lives naturally in riverine, brackish and estuarine ecosystems, and $V$. cholerae non$\mathrm{O} 1 /$ non-O139 is frequently isolated from aquatic environments as well as in seafood. In Malaysia, cholera due to $V$. cholerae poses a public health problem as sporadic outbreaks occur periodically [8]. The recruitment of foreign labour force from other cholera-endemic countries may foster the migration of strains into Malaysia, thus causing further outbreaks [9].

On the other hand, V. parahaemolyticus has been recognized as the leading cause of human gastroenteritis associated with seafood consumption in Asia and other parts of the world [10, 11, 12, 13]. Many researchers reported the abundance of $V$. parahaemolyticus during summer in temperate zone when temperature was above $25^{\circ} \mathrm{C}[14,15,16]$, whereas the organism is expected to be prevalent throughout the year in the tropical zone like Malaysia [17]. It is known that most strains of pathogenic $V$. parahaemolyticus can produce either thermostable 
direct hemolysin (TDH), TDH-related hemolysin (TRH) or both $[18,19,20]$ recognized as two major virulence factors for the pathogenesis of $V$. parahaemolyticus $[19,21]$. Application of PCR specific for the virulence genes $(t d h \& t r h)$ will help in detection of pathogenic V. parahaemolyticus. Most of $V$. parahaemolyticus isolates from the environmental and seafood samples are known to be negative for $t d h$ and $t r h$ and not pathogenic [21,22].

tox $\mathrm{R}$ gene which is involved in the regulation of gene expression in Vibrio species has also been characterized. This gene is shown to be present in all of the $V$. parahaemolyticus and $V$. cholerae isolates and could be used as target gene to develop method for specific detection of $V$. parahaemolyticus [23, 24]. Molecular typing procedures are applied to show clonal and close relationship between isolates of one species. In this present study, REP-PCR genomic fingerprinting was used to determine relatedness among strains of Vibrio spp. from Bachok, Kelantan. Previous study [25] has shown that REP-PCR is the most discriminatory compared to RAPD, pulsed-field gel electrophoresis, and ribotyping.

The aims of this study were to detect the presence of $V$. parahaemolyticus and $V$. cholerae in various waterways of Bachok, Kelantan, to characterize the virulence properties of the recovered environmental $V$. parahaemolyticus isolates, and to analyse the genetic relatedness among the isolates by REP-PCR which targets conserved repetitive elements that are distributed throughout the genome.

\section{MATERIALS AND METHODS}

\section{Sample collection}

A total of 50 water samples were collected from various waterways including river water $(n=39)$, sea water $(n=9)$ and waterfall $(n=2)$ in Bachok, Kelantan from June 16 to 18, 2008 [Table 1]. Samples were collected in pre-sterilized bottles and were kept on ice and transported to the laboratory to be processed within 3 hours.

\section{Sample processing and isolation of $V$. cholerae and V. parahaemolyticus}

$100 \mathrm{ml}$ of water samples (if turbid, prefiltered with sterile Whatman filter Type 1) were filtered through 0.45 - $\mu \mathrm{m}$-pore-size gridded membrane filters (Sartorius, Germany). The membrane filters were overlaid on CHROMagar $^{\mathrm{TM}}$ Vibrio agar and incubated for $16-18 \mathrm{~h}$ at $37^{\circ} \mathrm{C}$. Visible colonies that were blue and purple were counted as presumptive $V$. cholerae and $V$. parahaemolyticus, respectively [26].
Vibrio concentrations were expressed as colonyforming units (cfu) per $100 \mathrm{ml}$ of water.

\section{Biochemical tests}

Presumptive $V$. cholerae and $V$. parahaemolyticus colonies were picked and streaked on Nutrient agar (Oxoid, England) supplemented with $3 \% \mathrm{NaCl}$. These colonies were characterized using 3 types of biochemical tests consisting of Triple Sugar Iron Test, Oxidase Test and String Test before being subjected to PCR confirmation.

\section{DNA extraction}

A well isolated single colony grown on nutrient agar $(3 \% \mathrm{w} / \mathrm{v}, \mathrm{NaCl})$ was picked and mixed thoroughly in $50 \mu 1$ sterile distilled water. The cell suspension was then vortexed to disperse the cells in the water. The suspended cells were boiled at $99^{\circ} \mathrm{C}$ for 5 minutes to allow cell lysis. Immediately after that, the tubes were placed on ice for 10 minutes. Using a microcentrifuge, the cell lysate were centrifuged and clear supernatant was transferred into new tubes for PCR analysis.

\section{PCR confirmation}

Primer sequences, expected amplicon sizes and annealing temperature are referred in Table 2. All PCRs were performed in $0.2 \mathrm{ml}$ microfuge tubes using $25 \mathrm{ml}$ of reaction volume in a Thermal cycler (Eppendorf Mastercycler, Germany). Polymerase chain reaction (PCR) targeting tox $\mathrm{R}$ genes unique to $V$. cholerae $(V c-t o x \mathrm{R})$ and $V$. parahaemolyticus $(V p-$ tox $\mathrm{R}$ ) were used to confirm biochemical results and for detection of virulence genes $t d h$ and $t r h$ based on published protocols $[24,27,28]$.

\section{REP-PCR}

The REP-PCR of $V$. cholerae and $V$. parahaemolyticus isolates were initially performed using four different REP primers to determine their usefulness. However, only primer REP I gave multiple and reproducible bands (data not shown) and hence it was used for subsequent analysis. Amplification was performed in $25 \mu \mathrm{l}$ volume containing $5 \mu 1$ of $5 \mathrm{X}$ buffer (without $\mathrm{MgCl}_{2}$ ), 2.5 $\mathrm{mM}$ dNTPs, $0.25 \mu \mathrm{l}$ primer $(100 \mu \mathrm{M} / \mu \mathrm{l}), 5 \mathrm{U} / \mu \mathrm{l}$ of Taq polymerase, $25 \mathrm{mM} \mathrm{MgCl}$. The PCR conditions included an initial cycle of $94^{\circ} \mathrm{C}$ for $5 \mathrm{~min}, 33^{\circ} \mathrm{C}$ for 5 $\min , 68^{\circ} \mathrm{C}$ for $5 \mathrm{~min}$ followed by 35 cycles of $94^{\circ} \mathrm{C}$, $1 \mathrm{~min}, 40^{\circ} \mathrm{C}, 1 \mathrm{~min}$ and $68^{\circ} \mathrm{C}, 2 \mathrm{~min}$. Final extension step at $68^{\circ} \mathrm{C}$ for $1 \mathrm{~min}$. The PCR amplification products were fractioned by electrophoresis through $1.5 \%$ agarose gel and detected by staining with ethidium bromide $(0.5 \mu \mathrm{g} / \mathrm{ml})$. 
Table 1. Sites and coordinates of sampling stations in the waterways of Bachok.

\begin{tabular}{|c|c|c|c|}
\hline \multirow{2}{*}{ No. } & \multicolumn{2}{|c|}{ Coordinate } & \multirow{2}{*}{ Sites } \\
\hline & Latitude & Longitude & \\
\hline 1 & $\mathrm{~N} 05^{\circ} 53.374^{\prime}$ & E $102^{\circ} 28.494^{\prime}$ & Kg. Pak Makyong Jetty \\
\hline 2 & $\mathrm{~N} 05^{\circ} 52.796^{\prime}$ & E $102^{\circ} 28.223^{\prime}$ & Near Kg. Makyong Jetty \\
\hline 3 & $\mathrm{~N} 05^{\circ} 52.467^{\prime}$ & E $102^{\circ} 27.707^{\prime}$ & Kg.Siam River \\
\hline 4 & $\mathrm{~N} 05^{\circ} 52.110^{\prime}$ & E $102^{\circ} 27.314^{\prime}$ & Kg. Lembah River \\
\hline 5 & $\mathrm{~N} 05^{\circ} 51.287^{\prime}$ & E $102^{\circ} 26.594^{\prime}$ & Kg.Ajin river \\
\hline 6 & N $05^{\circ} 50.993^{\prime}$ & E $102^{\circ} 26.340^{\prime}$ & Semerak River \\
\hline 7 & $\mathrm{~N} 05^{\circ} 52.049^{\prime}$ & E $102^{\circ} 29.484^{\prime}$ & Kg. Cerang Ruku \\
\hline 8 & $\mathrm{~N} 05^{\circ} 52.281^{\prime}$ & E $102^{\circ} 29.310^{\prime}$ & Semerak River \\
\hline 9 & $\mathrm{~N} 05^{\circ} 52.328^{\prime}$ & E $102^{\circ} 29.325^{\prime}$ & Semerak River \\
\hline 10 & $\mathrm{~N} 05^{\circ} 52.543^{\prime}$ & E $102^{\circ} 29.343^{\prime}$ & Semerak River \\
\hline 11 & $\mathrm{~N} 05^{\circ} 52.650^{\prime}$ & E $102^{\circ} 28.900^{\prime}$ & Semerak River \\
\hline 12 & N $05^{\circ} 53.099^{\prime}$ & E $102^{\circ} 28.871^{\prime}$ & Semerak River \\
\hline 13 & $\mathrm{~N} 05^{\circ} 53.477^{\prime}$ & E $102^{\circ} 28.739^{\prime}$ & Semerak River \\
\hline 14 & N $05^{\circ} 53.724^{\prime}$ & E $102^{\circ} 29.060^{\prime}$ & Semerak River \\
\hline 15 & $\mathrm{~N} 05^{\circ} 53.442^{\prime}$ & E $102^{\circ} 28.636^{\prime}$ & Opposite Kg.Makyong Jetty \\
\hline 16 & N $06^{\circ} 07.499^{\prime}$ & E $102^{\circ} 22.320^{\prime}$ & Kuala Kemasin \\
\hline 17 & $\mathrm{~N} 06^{\circ} 06.947^{\prime}$ & E $102^{\circ} 21.617^{\prime}$ & Pantai Irama River Mouth \\
\hline 18 & $\mathrm{~N} 06^{\circ} 04.163^{\prime}$ & E $102^{\circ} 23.889^{\prime}$ & Kuala Melawi River mouth \\
\hline 19 & $\mathrm{~N} 05^{\circ} 53.361^{\prime}$ & E $102^{\circ} 30.254^{\prime}$ & Kg.Tok Bali \\
\hline 20 & $\mathrm{~N} 05^{\circ} 52.991^{\prime}$ & E $102^{\circ} 52.170^{\prime}$ & Kg. Semerak \\
\hline 21 & $\mathrm{~N} 05^{\circ} 52.376^{\prime}$ & E $102^{\circ} 32.101^{\prime}$ & Kg. Dalam \\
\hline 22 & $\mathrm{~N} 05^{\circ} 55.113^{\prime}$ & E $102^{\circ} 29.179^{\prime}$ & Tok Bali \\
\hline 23 & $\mathrm{~N} 05^{\circ} 57.178^{\prime}$ & E $102^{\circ} 26.390^{\prime}$ & Sg. Gali (Jetty) \\
\hline 24 & N $05^{\circ} 57.149^{\prime}$ & E $102^{\circ} 26.913^{\prime}$ & Sg. Gali (Near River Mouth) \\
\hline 25 & $\mathrm{~N} 05^{\circ} 51.901^{\prime}$ & E $102^{\circ} 29.637^{\prime}$ & Semerak River \\
\hline 26 & N $05^{\circ} 51.094^{\prime}$ & E $102^{\circ} 25.231^{\prime}$ & Semerak River \\
\hline 27 & N $05^{\circ} 54.807^{\prime}$ & E $102^{\circ} 22.533^{\prime}$ & Temusu Telok Lubok \\
\hline 28 & $\mathrm{~N} 05^{\circ} 54.524^{\prime}$ & E $102^{\circ} 22.623^{\prime}$ & Sg. Tasek \\
\hline 29 & $\mathrm{~N} 05^{\circ} 57.843^{\prime}$ & E $102^{\circ} 21.086^{\prime}$ & Irrigation channel \\
\hline 30 & $\mathrm{~N} 05^{\circ} 54.141^{\prime}$ & $\mathrm{E} 102^{\circ} 21.531^{\prime}$ & Sg. Tasek (Mid River) \\
\hline 31 & $\mathrm{~N} 05^{\circ} 54.391^{\prime}$ & E $102^{\circ} 20.953^{\prime}$ & Upper Sg.Tasek \\
\hline 32 & $\mathrm{~N} 05^{\circ} 49.872^{\prime}$ & E $102^{\circ} 25.017^{\prime}$ & Near Bkt. Awang \\
\hline 33 & $\mathrm{~N} 05^{\circ} 49.653^{\prime}$ & E $102^{\circ} 28.185^{\prime}$ & Near Kg. Tok Luchar \\
\hline 34 & $\mathrm{~N} 06^{\circ} 01.207^{\prime}$ & E $102^{\circ} 24.960^{\prime}$ & Rekang River \\
\hline 35 & $\mathrm{~N} 06^{\circ} 01.240^{\prime}$ & E $102^{\circ} 25.135^{\prime}$ & Sg.Rekang \\
\hline 36 & $\mathrm{~N} 05^{\circ} 59.755^{\prime}$ & E $102^{\circ} 25.814^{\prime}$ & Sg.Dua (IOES) \\
\hline 37 & $\mathrm{~N} 05^{\circ} 59.307^{\prime}$ & E $102^{\circ} 26.044^{\prime}$ & Sg. Limau Nipis \\
\hline
\end{tabular}




\begin{tabular}{|c|c|c|c|}
\hline 38 & $\mathrm{~N} 04^{\circ} 31.978^{\prime}$ & E $101^{\circ} 25.568^{\prime}$ & Jeram Pasu \\
\hline 39 & $\mathrm{~N} 05^{\circ} 44.450^{\prime}$ & E $102^{\circ} 22.615^{\prime}$ & Jeram Linang \\
\hline 40 & $\mathrm{~N} 06^{\circ} 01.903^{\prime}$ & E $102^{\circ} 25.780^{\prime}$ & Kg. Rekang \\
\hline 41 & $\mathrm{~N} 06^{\circ} 01.510^{\prime}$ & E $102^{\circ} 26.015^{\prime}$ & Kuala Rekang \\
\hline 42 & $\mathrm{~N} 05^{\circ} 56.811^{\prime}$ & E $102^{\circ} 27.488^{\prime}$ & Kampung Sg. Dua \\
\hline 43 & $\mathrm{~N} 05^{\circ} 55.667^{\prime}$ & E $102^{\circ} 28.540^{\prime}$ & Tok Bali \\
\hline 44 & $\mathrm{~N} 05^{\circ} 55.048^{\prime}$ & E $102^{\circ} 28.364^{\prime}$ & Tok Bali \\
\hline 45 & $\mathrm{~N} 05^{\circ} 43.190^{\prime}$ & E $102^{\circ} 15.628^{\prime}$ & Hutan Lipur Bukit Bakar Semerak \\
\hline 46 & $\mathrm{~N} 06^{\circ} 07.039^{\prime}$ & E $102^{\circ} 17.753^{\prime}$ & Sg. Pengkalan Datu \\
\hline 47 & $\mathrm{~N} 06^{\circ} 09.914^{\prime}$ & E $102^{\circ} 20.657^{\prime}$ & Kuala Senok \\
\hline 48 & $\mathrm{~N} 06^{\circ} 09.933^{\prime}$ & E $102^{\circ} 20.152^{\prime}$ & Sg. Senok \\
\hline 49 & $\mathrm{~N} 06^{\circ} 08.323^{\prime}$ & E $102^{\circ} 19.389^{\prime}$ & Pantai Sabak \\
\hline 50 & $\mathrm{~N} 06^{\circ} 07.678^{\prime}$ & E $102^{\circ} 22.127^{\prime}$ & Kuala Kemasin \\
\hline
\end{tabular}

Table 2. List of primers, target genes and amplicon sizes.

\begin{tabular}{|c|c|c|c|c|}
\hline & Primers and sequences ( $5^{\prime}$ to $\left.3^{\prime}\right)$ & Amplicon size (bp) & $\begin{array}{c}\text { Annealing } \\
\text { Temperature }\left({ }^{\circ} \mathrm{C}\right)\end{array}$ & Reference \\
\hline $\begin{array}{l}\text { Vp-toxR1 } \\
\text { Vp-toxR2 }\end{array}$ & $\begin{array}{l}\text { GTC TTC TGA CGC AAT CGT TG } \\
\text { ATA CGA GTG GTT GCT GTC ATG }\end{array}$ & 368 & 63 & [24] \\
\hline $\mathrm{Vc}-\operatorname{tox} R 1$ & CCT TCG ATC CCC TAA GCA ATA & 779 & 60 & {$[28]$} \\
\hline Vc-toxR2 & AGG GTT AGC AAC GAT GCG TAA G & & & \\
\hline$t d h 1$ & CCA CTA CCA CTC TCA TAT GC & 251 & 55 & [27] \\
\hline$t d h 2$ & GGT ACT AAA TGG CTG ACA TC & & & \\
\hline $\operatorname{trh} 1$ & GGC TCA AAA TGG TTA AGC G & 250 & 55 & [27] \\
\hline $\operatorname{trh} 2$ & CAT TTC CGC TCT CAT ATG C & & & \\
\hline REP I & GCG CCG ICA TGC GGC ATT & Variable & 40 & {$[38]$} \\
\hline
\end{tabular}

Gel documentation and image analysis

After de-staining, the gel was photographed using the GelDoc system (Bio-Rad). The fingerprints were analyzed using a computer software package, GelComparII Version 2.0 software (Applied Math, Belgium). After background subtraction and gel normalization, the fingerprints were subjected to cluster analysis using the unweighted pair group method with arithmetic mean (UPGMA). This program was used to construct a dendrogram and to calculate similarity values (Dice Coefficient, F).

\section{RESULTS AND DISCUSSION}

The aim of this study was to determine whether Vibrio cholerae and other Vibrio spp. such as $V$.parahaemolyticus were present in water bodies of Bachok, Kelantan. Such information may allow us to determine the possible influence of water sources on the infection and disease in the community.

\section{Identification of $\boldsymbol{V}$. cholerae and V parahaemolyticus}

A total of 50 water samples were screened for the presence of $V$. cholerae and $V$. parahaemolyticus. Based on the selective medium (CHROMagar ${ }^{\mathrm{TM}}$ Vibrio), distinct mauve coloured colonies (presumptive $V$. parahaemolyticus) and blue colonies (presumptive $V$. cholerae/ $V$. vulnificus) were present in 45 (average density of $2.4 \times 10^{4} \mathrm{cfu} / 100 \mathrm{ml}$ ) and 49 (average density of $4.4 \times 10^{4} \mathrm{cfu} / 100 \mathrm{ml}$ ) water samples, respectively. A total of 200 isolates were subjected to biochemical tests consisting of Triple Sugar Iron Test, Oxidase Test and String Test. 
Table 3: Results of biochemical tests used to screen for $V$. cholerae $^{a}$ and $V \cdot$ parahaemolyticus $^{b}$

\begin{tabular}{ccccc}
\hline $\begin{array}{c}\text { Biochemical } \\
\text { tests }\end{array}$ & $\begin{array}{c}\text { V.cholerae } \\
\text { reaction }\end{array}$ & $\begin{array}{c}\text { No. of isolates with } \\
\text { same reaction as } \\
\text { V.cholerae }\end{array}$ & $\begin{array}{c}\boldsymbol{V} \text {. } \\
\text { parahaemolyticus } \\
\text { reaction }\end{array}$ & $\begin{array}{c}\text { No. of isolates with same } \\
\text { reaction as V.parahaemolyticus }\end{array}$ \\
\hline $\begin{array}{c}\text { Triple Sugar } \\
\text { Iron Test }\end{array}$ & $\mathrm{A} / \mathrm{A}$ & 56 & $\mathrm{~K} / \mathrm{A}$ & 45 \\
Oxidase Test & + & 40 & + & 50 \\
String Test & + & 33 & + & 29 \\
\hline
\end{tabular}

${ }^{a}$ A total of 86 bacterial isolates were subjected to each biochemical test

${ }^{b}$ A total of 114 bacterial isolates were subjected to each biochemical test

${ }^{c} \mathrm{~A} / \mathrm{A}$, acid slant (yellow) and acid butt (yellow)

${ }^{d} \mathrm{~K} / \mathrm{A}$, alkaline slant (purple) and acid butt (yellow)

Biochemical tests results showed that 33 isolates presented the characteristics of $V$. cholerae and 29 isolates for $V$. parahaemolyticus which were mostly found in river water samples (Table 3). All the presumptive $V$. cholerae and $V$. parahaemolyticus were subjected to PCR analysis for further confirmation.

PCR confirmation of $V c$-toxR, $V p$-tox $R, t d h$ and trh genes

Based on PCR method, a $800 \mathrm{bp}$ fragment of toxR gene was amplified in 3 strains of $V$. cholerae (Figure 1) and a $368 \mathrm{bp}$ tox $\mathrm{R}$ gene in 25 strains of $V$. parahaemolyticus (Figure 2). Due to the limitation of the biochemical tests, there were a number of false positives. Since most of the Vibrio species showed the same appearance and characteristics, it was difficult to differentiate or confirm different species by just using biochemical tests. Moreover, presumptive blue colonies from the selective medium (CHROMagar ${ }^{\mathrm{TM}}$ Vibrio) used in the study represent either $V$. cholerae or $V$. vulnificus. This further reduced the chances to pick the presumptive $V$. cholerae colonies. In future, more tests such as arginine dihydrolase and esculin hydrolysis tests [29] which are specific for $V$. cholerae should be included to reduce the number of false positives. The low isolation rate of Vibrio cholerae in the present study could, however, also have been affected by the isolation method used in this study which excluded the enrichment step. In this study, the direct plating technique was used because of time constraint in the field. Furthermore, $V$. cholerae strains under certain conditions assume spore-like or dormant forms (viable but non-culturable (VBNC)). These forms cannot readily be made culturable and so most conventional tests fail to detect them [30,31].

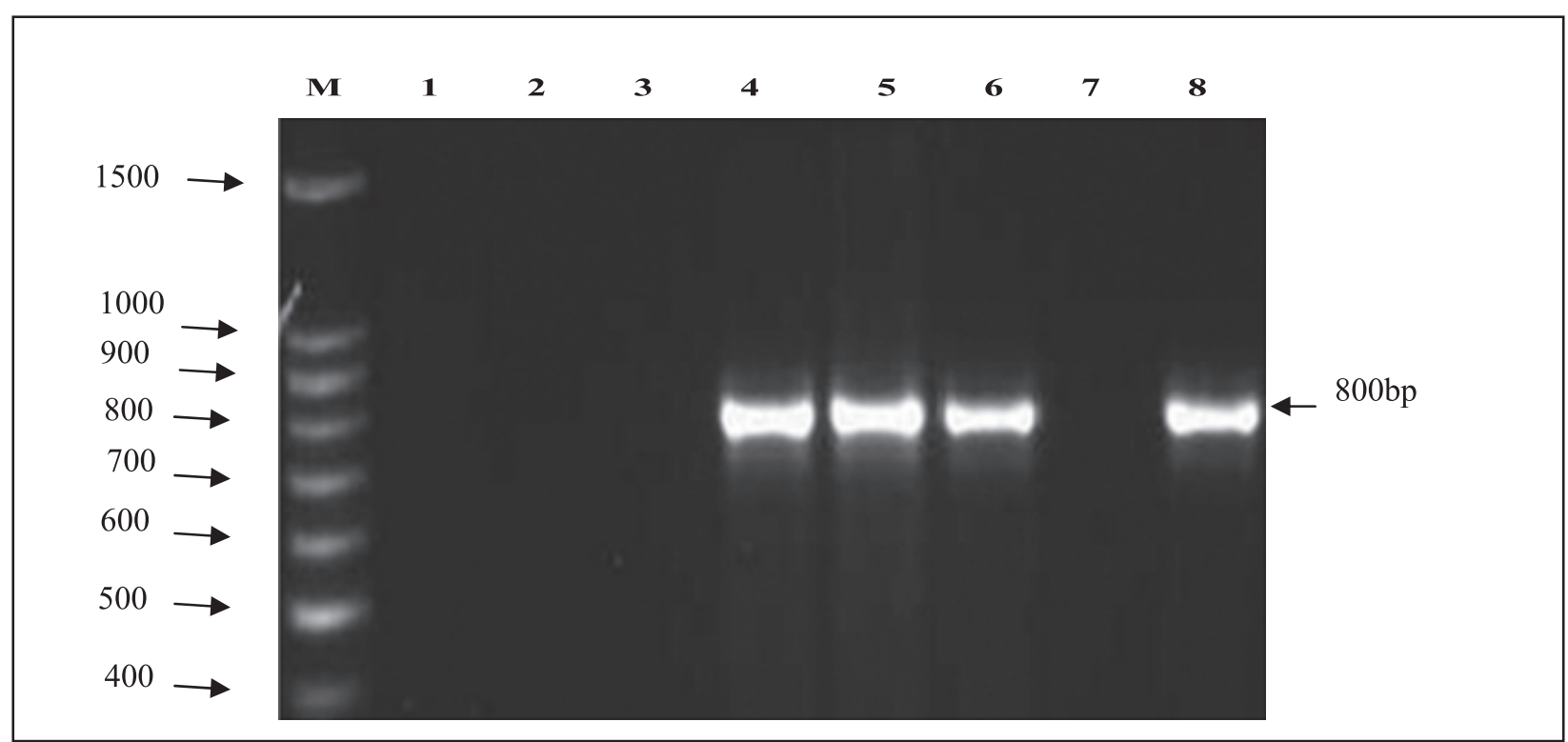

Figure 1. PCR for the detection of toxR gene, 800bp) unique to $V$. cholerae strain. Lane M: DNA ladder (100 bp); lane 7, negative control; lanes 4-6, V.cholerae isolates; lane 8, positive control. 


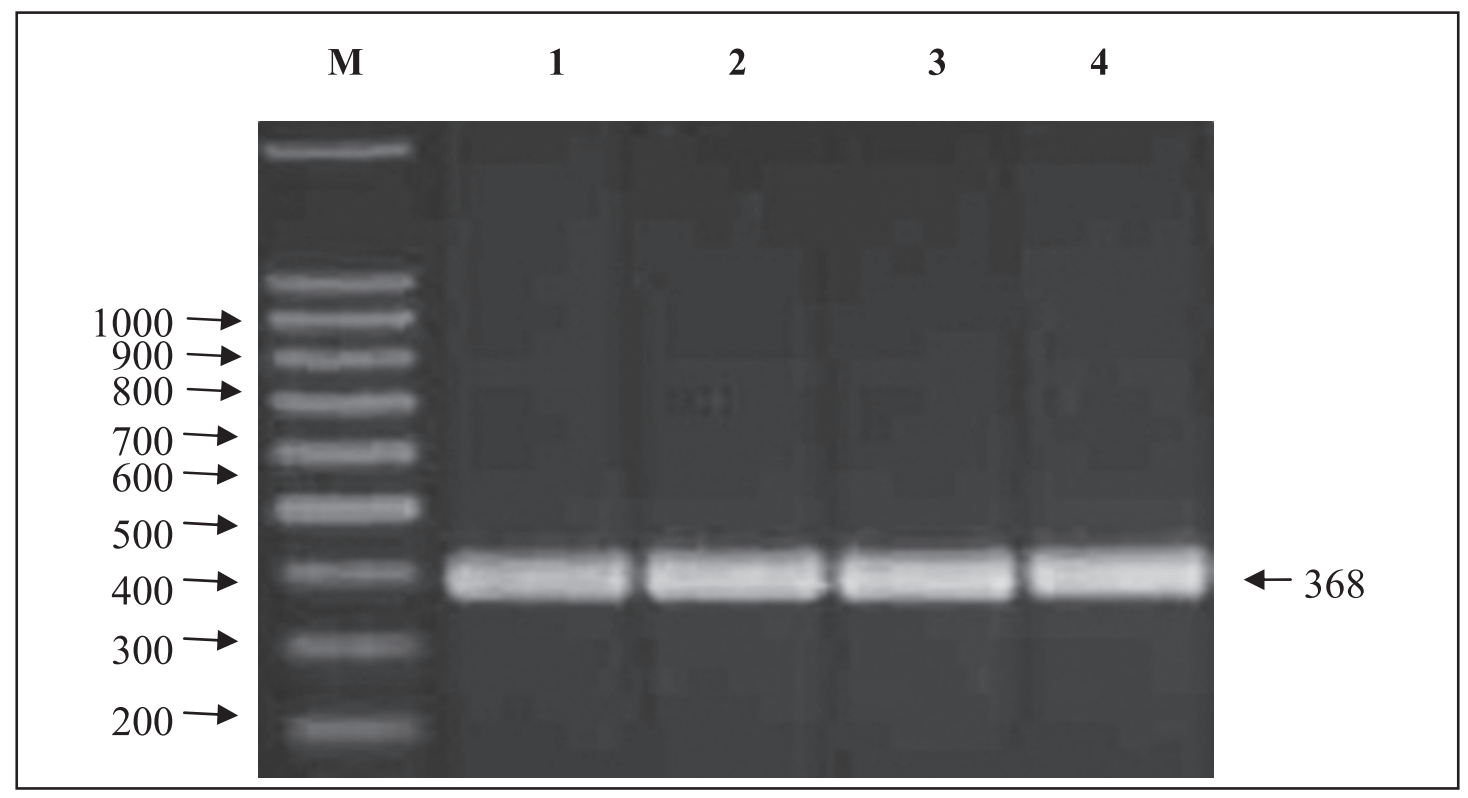

Figure 2. PCR for the detection of toxR gene (368bp). Lane M: DNA ladder (100bp), Lanes 1-3: $V$. parahaemolyticus isolates, Lane 4: PCR positive control

Although $V$. parahaemolyticus is widely distributed in the coastal environments all over the world, most of the environmental strains are not pathogenic to humans. In this study all the confirmed isolates of $V$. parahaemolyticus were tested for the presence of $t d h$ and trh genes by PCR. None of the isolates were found to be positive for both virulence genes. This suggests that most of the environmental $V$. parahaemolyticus strains are non-toxin producers [32]. In addition, the prevalence of $t r h^{+}$strains in environmental samples and seafood products was reported to be very low in comparison to clinical strains [33, 34, and 35]. However, the presence of non-toxigenic $V$. parahaemolyticus in Bachok, Kelantan does not mean that the water is safe for human consumption as the guts serve as the site where these non-toxigenic strains can be converted into toxigenic ones [36].

\section{REP-PCR}

Molecular typing was used for epidemiological studies as it provides the information on genetic relatedness of different bacterial strains, the source of infection, molecular markers of virulent and host specific strains [37]. In this study, 28 strains of Vibrios were subjected to REP-PCR analysis. Isolates from different water samples were found to be very diverse in their REP-PCR patterns, with 28 different patterns among 28 strains (Figure 3). Primer REP I successfully generated fingerprints consisted of 4 to 9 bands ranging from 250 to $4000 \mathrm{bp}$ among the
V.parahemolticus (Figure 4) and V. cholerae strains (Figure 5). It was evident that majority of the strains exhibited patterns with small number of REP-PCR products. However all the strains demonstrated a common band approximately $350 \mathrm{bp}$. The REP-PCR amplification was also repeated at least three times to evaluate its reproducibility. The results revealed consistent band amplification in all the REP-PCR assays. The feasibility of this molecular typing method depends on the use of various primers and experimental conditions.

Similarity analysis was performed by using the Dice coefficient and clustering was done by UPGMA. Based on $70 \%$ similarity, the dendrogram constructed elucidated two main clusters, A and B (Figure 3). Cluster A consisted only $V$. cholerae strains and Cluster B with $V$. parahaemolyticus which was further subdivided into B1-B6. A distinct grouping between clusters was apparent pertaining to the different species, source of isolation and geographical location. Three pairs of the strains, VPH16 (Kuala Kemasin) and VPH25 (Semerak River), VPH41 (Kuala Rekang) and VPH44 (Tok Bali) and VPH40 (Kampung Rekang) with VPH42 (Kampung Sungai Dua) showed close relatedness by sharing more than $90 \%$ similarity, as shown in the dendrogram (Figure 3). Interestingly strain VPH 16 which was isolated from water sample obtained from mangrove site and strain VPH 25 from river samples were grouped together with similarity $>90 \%$ in spite of different geographical areas. Therefore, it 
Dice (Tol 1.0\%-1.0\%) $(H>0.0 \% S>0.0 \%)$ [0.0\%-100.0\%]

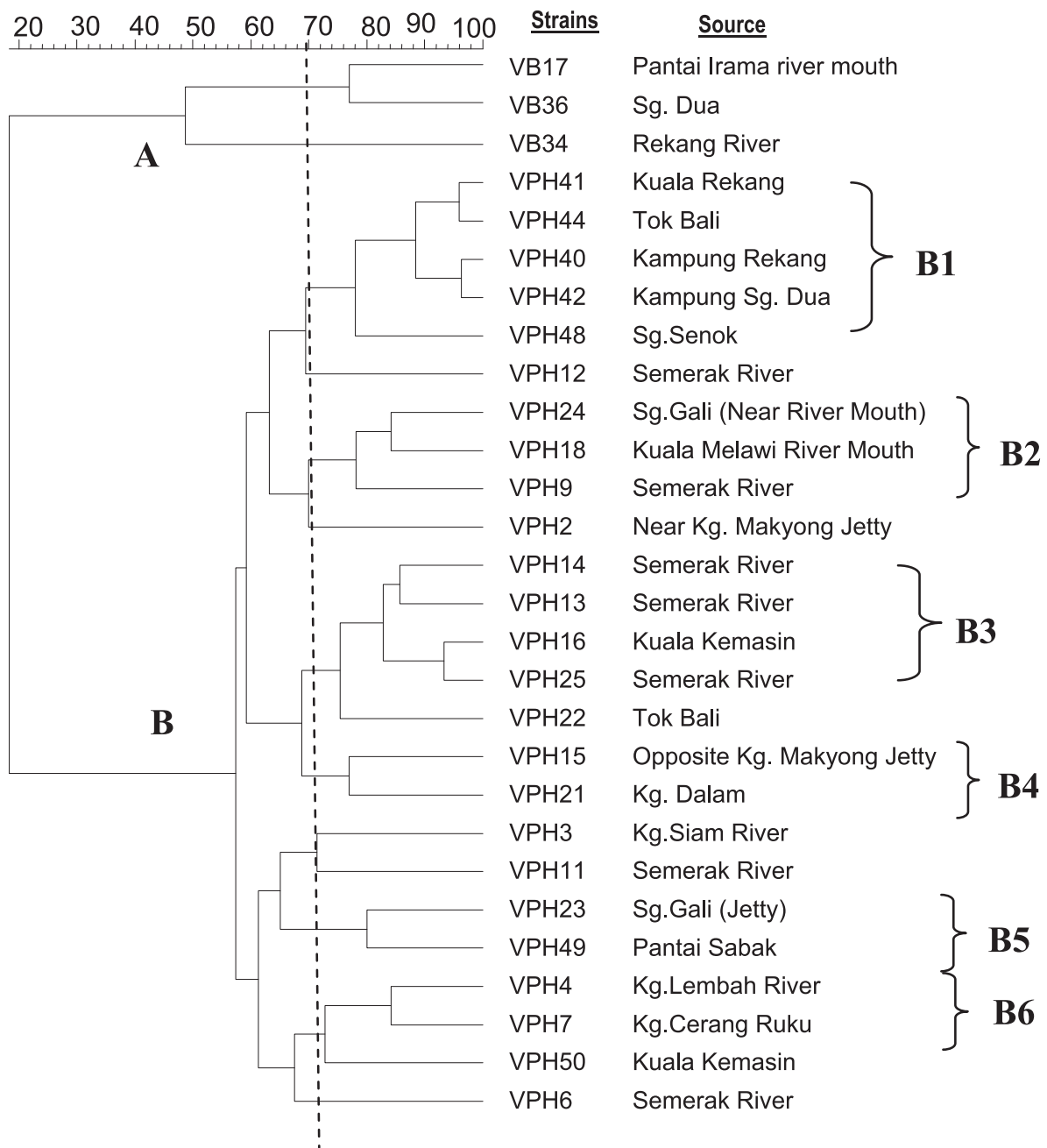

Figure 3. Dendrogram showing cluster analysis of REP-PCR profiles of selected environmental samples (Cluster A represents $V$. cholerae strains and cluster B represents $V$. parahaemolyticus strains). Within cluster B, there are 6 subclusters, B1-B6.

is suggested that the strains could have originated from the same clonal linage of $V$. parahaemolyticus. There have been several possible means of transfer for $V$. parahaemolyticus including infected humans, tidal drift, and ecological relationship with other marine organisms.

However, the REP-PCR patterns of the majority of the strains demonstrated similarities below 90\%. In a previous study [39], strains with similarities below $90 \%$ are considered genetically unrelated. Thus, based on similarity using Dice coefficient, Vibrio spp. isolated from Bachok, Kelantan were genetically diverse.

In conclusion, this study provided new information with regards to the presence of $V$. cholerae and $V$. parahaemolyticus strains in various waterways of Bachok Kelantan. Although conventional culture methods can detect the bacteria, PCR technique was more reliable, since they are specific in the detection of a target bacterium and could differentiate 


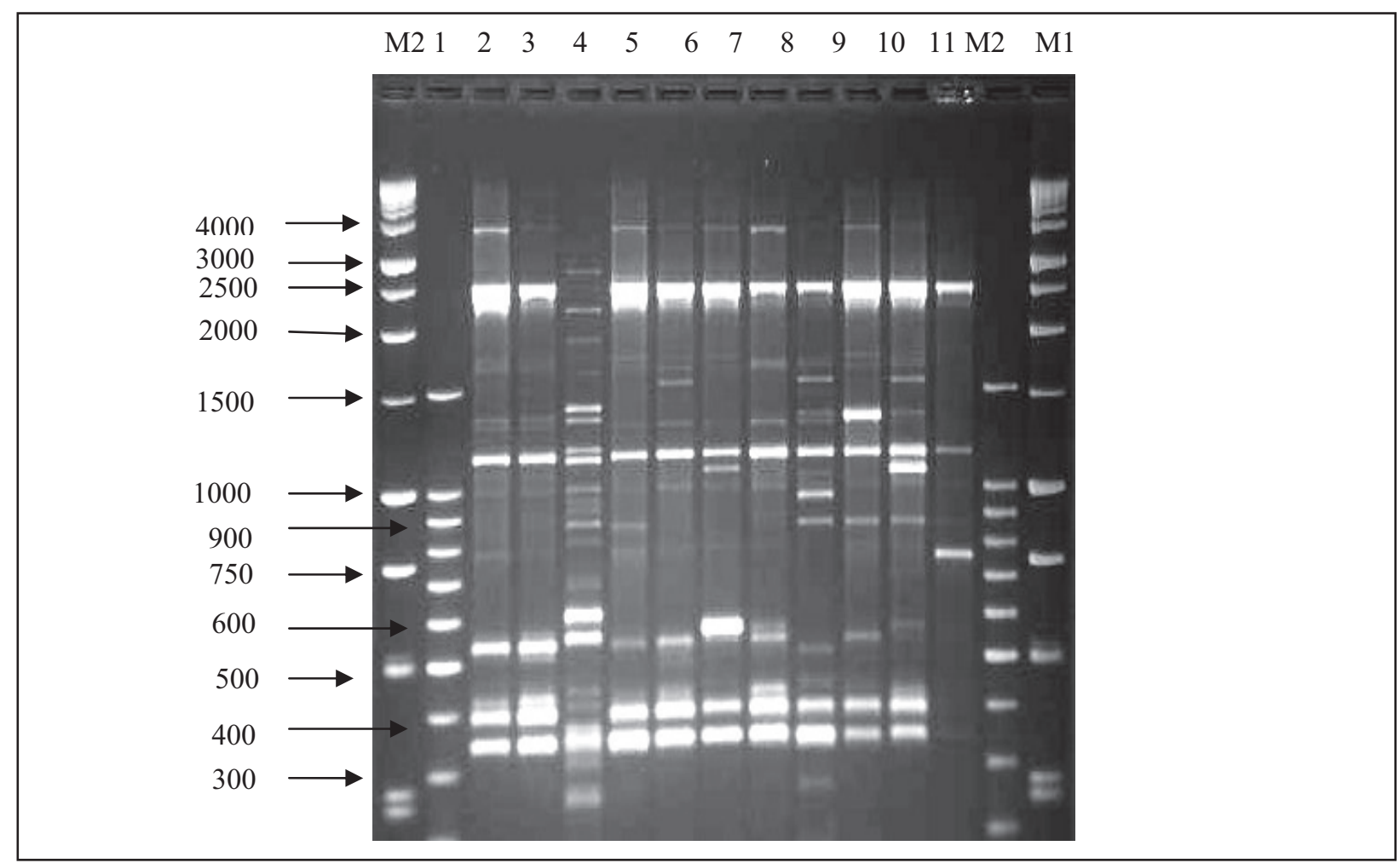

Figure 4. Representative REP-PCR Fingerprints of $V$. parahaemolyticus (VPH) M1=1kb DNA Standard, M2 $=100 \mathrm{bp}$ DNA marker (Promega). Lanes 1-3,Positive control strains; Lane 4,VPH 12;Lane 5, VPH 2; Lane 6,VPH 3;Lane 7, VPH 4; Lane 8, VPH 6;Lane 9, VPH 7; Lane 10, VPH 9; Lane 11, VPH 11

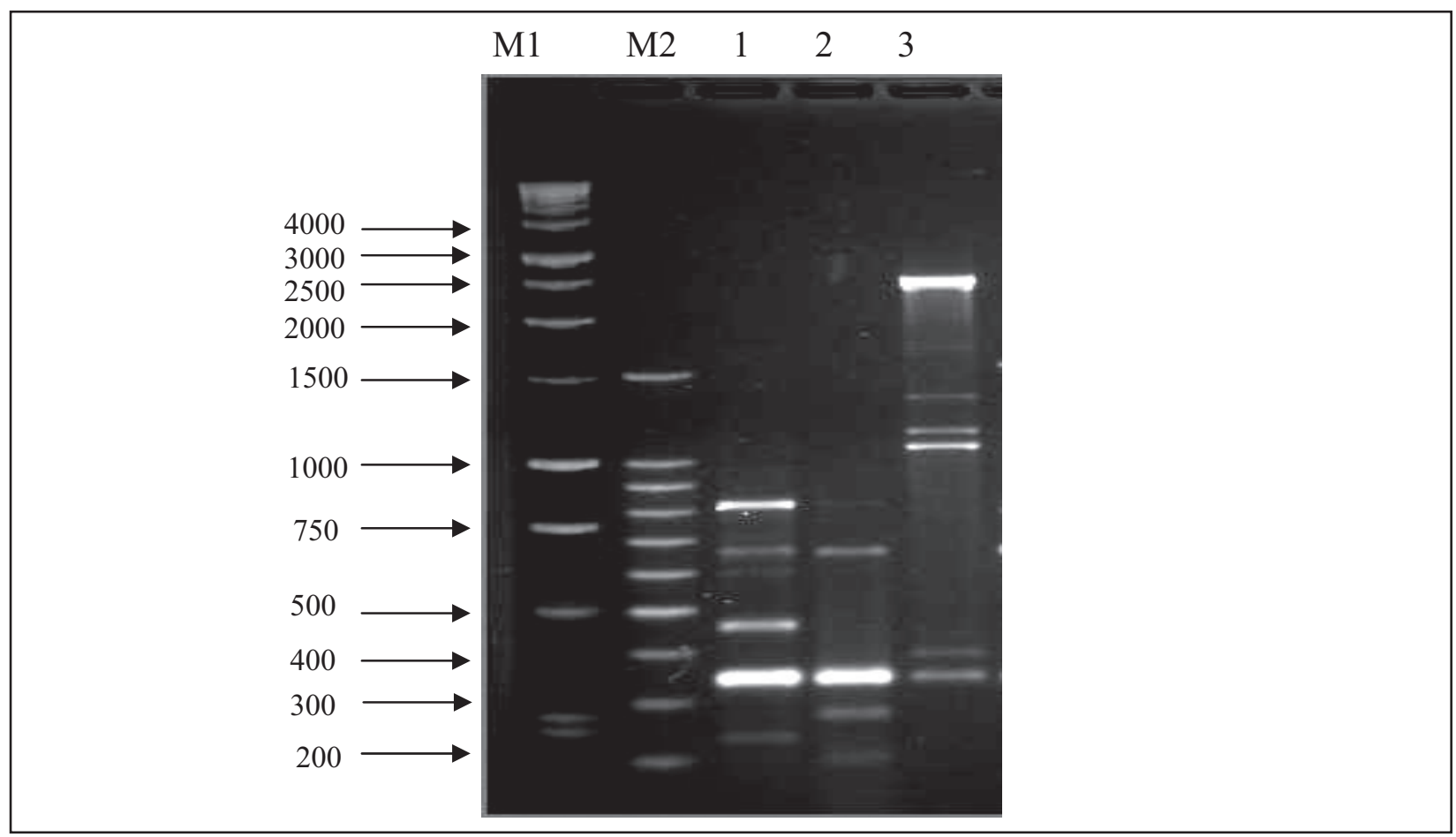

Figure 5. Representative REP-PCR fingerprints of $V$.cholerae strains $\mathrm{M} 1=1 \mathrm{~kb}$ DNA marker, M2 = 100bp DNA marker (Promega). Lane 1, VB 17; Lane 2, VB 34; Lane 3, VB 36. 
pathogenic from non-pathogenic strains. REP-PCR generated fingerprints have been successfully used to discriminate the diverse bacterial population.

\section{ACKNOWLEDGEMENTS}

The authors thank University of Malaya for the short term research grant (FS318/2008A) for this work. The authors would like to thank Tim Chuan Seet, Rathi, and Lim Sin Yun for technical assistance during the field sampling in Bachok, Kelantan.

\section{REFERENCES}

1. Colwell, R.R. (2004). Infectious disease and environment: cholera as a paradigm for waterborne disease. Int Microbiol 7: 285-289.

2. Summer, J.D.A., Osaka, K., Karunasager, I., Walkderhaug, M. and Bowers, J. (2001). Hazard identification, exposure assessment, and hazard characterization of Vibrio sp. in seafood. In Joint FAO/WHO Activities on Risk Assessment of Microbiological Hazards in Foods, pp. 1-105.

3. Thompson, F.L., Iida, T. and Swings, J. (2004). Biodiversity of vibrios. Microbiol Mol Biol Rev 68:403-431

4. Yuherman, Son R., Rusul G., Lum K.Y. and Jamakhair (2000). Genetic relatedness of Vibrio Cholerae $\mathrm{O} 1$ and non-O1 by ERIC Polymerase Chain Reaction and Pulse Field Gel Electrophoresis. Pakistan J Biol Sci 3(4): 621622.

5. Chen, C. H., Shimada, T., Elhadi, N., Radu, S. and Nishibuchi, M., (2004). Phenotypic and Genotypic Characteristics and Epidemiological Significance of $c t x+$ Strains of Vibrio cholerae Isolated from Seafood in Malaysia. Appl Environ Microbiol 70: 1964-1972.

6. Tanil G.B, Son R., Nishibuchi M., Raha AR., Napis S., Maurice L. and Gunsalam J.W. (2005) .Characterization of Vibrio parahaemolyticus isolated from coastal seawater in peninsular Malaysia. Southeast Asian J Trop Med Publ Health 36(4):940-5

7. Lesley M.B., Son R., Abdul R.B., Raha A.R., Suhaini N., Cheah Y.K., Chandrika M., Yousr A.H., Tunung R. and Nishibuchi M. (2005). Random Amplified Polymorphic DNA-PCR typing of Vibrio parahaemolyticus isolated from local cockles (Anadara granosa). Am J Immunol 1(1): $31-36$

8. Vadivelu, J., Iyer, L., Kshatriya, B.M. and Puthucheary, S.D. (2000). Molecular evidence of clonality amongst Vibrio cholerae O1 biotype El Tor during an outbreak in Malaysia. Epidemiol Infect 124: 25-30
9. Iyer, L. and Vadivelu, J. (2006). Molecular analysis of Vibrio cholerae strains isolated in Malaysia: Public health implications. Asia Pac J Publ Health 18(3): 33-41

10. Okuda, J., Ishibashi, M., Hayakawa, E., Nishino, T., Takeda, Y., Mukhopadhyay, A. K., et.al. (1997). Emergence of a unique O3:K6 clone of Vibrio parahaemolyticus in Calcutta, India, and isolation of strains from the same clonal group from Southeast Asian travelers arriving in Japan. J Clin Microbiol 35:3150-3155

11. Dileep, V., Kumar, H.S., Kumar, Y., Nishibuchi, M. and Karunasagar, I. (2003). Application of polymerase chain reaction for detection of Vibrio parahaemolyticus associated with tropical seafood and coastal environment. Lett Appl Microbiol 36: 423-427

12. Chiou, C.S., Hsu, S.Y., Chiu, S.I., Wang, T.K. and Chao, C.S. (2000). Vibrio parahaemolyticus serovar O3:K6 as cause of unusually high incidence of food-borne disease outbreaks in Taiwan from 1996 to 1999. J Clin Microbiol 38: 4621-4625

13. Robert-Pillot, A., Guénolé, A., Lesne, J., Delesmont, R., Fournier, J.M. and Quilici, M.L. (2004). Occurrence of the $t d h$ and trh genes in Vibrio parahaemolyticus isolates from waters and raw shellfish collected in two French coastal areas and from seafood imported into France. International J Food Microbiol 91: 319-325

14. Khan, A.A., McCarthy S., Wang R.F. and Cerniglia C.E. (2002). Characterization of United States outbreak isolates of Vibrio parahaemolyticus using enterobacterial repetitive intergenic consensus (ERIC) PCR and development of a rapid PCR method for detection of O3:K6 isolates. FEMS Microbiol Lett 206: 209-214

15. Centers for Disease Control and Prevention (CDC), (1998). Outbreak of Vibrio parahaemolyticus infections association with eating raw oysters - Pacific Northwest, 1997. Morb Mortal Wkly Rep 47:457-462

16. Centers for Disease Control and Prevention (CDC), (1999). Outbreak of Vibrio parahaemolyticus infection associated with eating raw oysters and clams harvested from Long Island Sound-Connecticut, New Jersey and New York, 1998. Morb Mortal Wkly Rep 48: 48-51

17. Elhadi, N., Radu, S., Chen C.H. and Nishibuchi, M. (2004). Prevalence of potentially pathogenic Vibrio species in the seafood marketed in Malaysia. J Food Prot 67: 1469-1475

18. Miyamoto, Y., Kato, T., Obara, Y., Akiyama, S., Takizawa, K. and Yamai, S. (1969). In vitro 
hemolytic characteristic of Vibrio parahaemolyticus: its close correlation with human pathogenicity. J Bacteriol 100:11471149.

19. Honda, T. and Iida, T. (1993).The pathogenicity of Vibrio parahaemolyticus and the role of thermostable direct haemolysin and related haemolysins. Rev Med Microbiol 4: 106-113.

20. Hervio-Heath, D., Colwell, R.R., Derrien, A., Robert-Pillot, A., Fournier, J.M. and Pommepuy, M. (2002). Occurrence of pathogenic vibrios in coastal areas of France. $J$ Appl Microbiol 92:1123-1135

21. Nishibuchi, M. and Kaper, J.B (1995) Thermostable direct haemolysin gene of Vibrio parahaemolyticus: a virulence gene acquired by a marine bacterium. Infect Immun 63:2093-2099

22. Joseph, S.W., Colwell, R.R. and Kaper, J.B. (1982). Vibrio parahaemolyticus and related halophilic vibrios. Crit Rev Microbiol 10:77-124

23. Bej, A.K., Patterson, D.P., Brasher, C.W., Vickery, M.C.L., Jones, D.D. and Kaysner, C.A. (1999). Detection of total and hemolysinproducing Vibrio parahaemolyticus in shellfish using multiplex PCR amplification of $t l, t d h$, and trh. J Microbiol Methods 36: 215-225

24. Kim, Y.B., Okuda, J., Matsumoto, C., Takahashi, N., Hashimoto,S. and Nishibuchi, M. (1999).Identification of Vibrio parahaemolyticus strains at the species level by PCR targeted to the tox R gene. J Clin Microbiol 37: 1173-1177

25. Wong, H. C., and Lin C.H. (2001). Evaluation of typing of Vibrio parahaemolyticus by three PCR methods using specific primers. J Clin Microbiol 39:4233-4240

26. Hara-Kudo Y., Nishina T., Nakagawa H., Konuma H., Hasegawa J. and Kumagai S. (2001). Improved method for detection of Vibrio parahaemolyticus in seafood. Appl Environ Microbiol 67:5819-5823

27. Tada, J., Ohashi, T., Nishimura, N., Shirasaki, Y., Ozaki, H., Fukushima, S., Takano, J., Nishibuchi, M. and Takeda, Y. (1992). Detection of the thermostable direct hemolysin gene $(t d h)$ and the thermostable direct hemolysin-related hemolysin gene (trh) of Vibrio parahaemolyticus by polymerase chain reaction. Mol Cell Probes 6: $477-487$

28. Rivera, I.N.G., Chun, J., Huq, A., Sack, R.B. and Colwell, R.R. (2001). Genotypes associated with virulence in environmental isolates of Vibrio cholerae. Appl Environ Microbiol 67: 24212429
29. Choopun, N., Louis, V. Huq, A. and Colwell R.R. (2002). Simple procedure for rapid identification of Vibrio cholerae from the aquatic environment. Appl Environ Microbiol 68:995998

30. Colwell, R.R. and Huq, A. (1994). Vibrio cholerae and Cholera: Molecular to Global Perspectives. Washington, DC: ASM Press, pp. 117-135.

31. Oliver, J. and Koper, J. (1997). Vibrio species In: Food Microbiology: Fundamentals and Frontiers. Washington DC: Editorial ASM Press, pp. 228-264

32. Tamrakar, A.K., Goel, A.K., Kamboj, D.V. and Singh, L. (2006). Surveillance methodology for Vibrio cholerae in environmental samples. Int $J$ Environ Health Res 16(4):305-12

33. Cook, D. W., Bowers, J. C. and DePaola, A. (2002). Density of total and pathogenic $(\mathrm{tdh}+)$ Vibrio parahaemolyticus in Atlantic and Gulf coast molluscan shellfish at harvest. $J$ Food Prot 65:1873-1880

34. Kiiyukia, C., Venkateswaran, K., Navarro, I. M., Nakano, H., Kawakami, H. and Hashimoto, H. (1989). Seasonal distribution of Vibrio parahaemolyticus serotypes along the oyster beds in Hiroshima coast. Journal of Faculty of Applied Biological Science, Hiroshima University, 28:49-61

35. Ogawa, H., Tokunou, H., Kishimoto, T., Fukuda, S., Umemura, K., and Takata, M. (1989). Ecology of Vibrio parahaemolyticus in Hiroshima Bay. Hiroshima. $J$ Vet Med 4: 47-57

36. Faruque, S.M., Albert, M.J. and Mekalanos, J.J. (1998). Epidemiology,genetics and ecology of toxigenic Vibrio cholerae. Microbiol Mol Biol Rev 62: 1301-1314

37. Olive, D. M. and Bean, P. (1999). Principles and applications of methods for DNA based typing of microbial organisms. J Clin Microbiol 37: 1661-1669

38. Navia, M.M, Capitano, L., Ruiz, J., Vargas M., Urassa H., Schellemberg D., Gascon J. and Vila, J. (1999). Typing and characterization of mechanisms of resistance of Shigella spp. isolated from faeces of children under 5 years of age from Ifakara, Tanzania. J Clin Microbiol 37: 3113-3117

39. Szczuka, E., and Kaznowski, A. (2004). Typing of clinical and environmental Aeromonas sp. strains by random amplified polymorphic DNA PCR, repetitive extragenic palindromic PCR, and enterobacterial repetitive intergenic consensus sequence PCR. J Clin Microbiol 42:220-228 